\title{
The Geology of the Faraday 2 Kimberlite, NWT, Canada
}

\author{
Lindsay Nelson', Casey Hetman², Michael Diering ${ }^{3}$ \\ ${ }^{1}$ Aurora Geosciences Ltd., Yellowknife, Canada, lindsay.nelson@aurorageosciences.com \\ ${ }^{2}$ SRK Consulting, Vancouver, Canada, chetman@srk.com \\ ${ }^{3}$ SRK Consulting, Vancouver, Canada, mdiering@srk.com
}

\section{Introduction}

The diamondiferous Faraday 2 kimberlite pipe is located in the southeastern Slave Craton of northern Canada. Faraday 2 is part of the Kelvin-Faraday kimberlite cluster, which consists of at least five irregular pipe-like bodies (Hobbes, Kelvin, Faraday 2, Faraday 3, and Faraday 1; listed from southwestnortheast) and associated kimberlite sheet complexes. The kimberlites subcrop below shallow lakes and their distribution follows a southwest-northeast lineament. The Gahcho Kué Diamond Mine also lies along this regional trend, approximately $10 \mathrm{~km}$ to the southwest of Faraday 2. Faraday 2 was first targeted as a result of kimberlite indicator mineral anomalies in glacial till and magnetic and gravity anomalies from geophysical surveying. De Beers Canada intersected kimberlite at Faraday 2 in 2001. Kennady Diamonds Inc. re-initiated exploration in the area in 2012 and has since completed extensive drilling and sampling programs. Faraday 2 has an irregular morphology and non-typical inclined orientation. To date, the pipe has been delineated over $450 \mathrm{~m}$; it varies in width between 20 and $60 \mathrm{~m}$ and between 60 and $90 \mathrm{~m}$ in vertical thickness. The pipe is inclined towards the northwest, turning further towards the west with increasing depth. The southeastern section of the kimberlite is inclined at $30^{\circ}$, steepening to $40^{\circ}$ as the kimberlite turns towards the west, and shallowing to between 0 and $20^{\circ}$ in the most northwesterly portion of the body. Several kimberlite units resulting from multiple emplacement events are present within Faraday 2. Volcaniclastic kimberlite is the dominant pipe infill, with lesser amounts of coherent and texturally transitional kimberlite.

\section{Evaluation}

Detailed logging of drill core and chip samples, petrographic studies, and diamond results were used to define the irregular external morphology and the internal geology of Faraday 2 (Figure 1). A total of 85 diamond drill holes were completed at Faraday 2 since 2012. In 2016, a 21-tonne bulk sample was collected using 11-inch diameter reverse circulation (RC) drilling. In 2017, a further 263 tonnes of kimberlite was collected from 29 11-inch diameter RC holes. Multiple petrographic investigations were completed, totaling 295 kimberlite and country rock thin sections from 40 diamond drill holes and 93 kimberlite thin sections from RC chip samples. A total of 6,788 $\mathrm{kg}$ of kimberlite drill core was processed by caustic fusion at the Geoanalytical Laboratories Diamond Services of the Saskatchewan Research Council (SRC); the diamond recoveries are presented in Table 1.

\begin{tabular}{|c|c|c|c|c|c|c|c|c|c|c|c|c|c|c|c|}
\hline \multirow[b]{2}{*}{ Unit } & \multirow[b]{2}{*}{$\begin{array}{c}\text { Sample Weight } \\
\text { (dry tonnes) }\end{array}$} & \multicolumn{12}{|c|}{ Number of Diamonds According to Sieve Size Fraction (mm) } & \multirow[b]{2}{*}{\begin{tabular}{|c|} 
Total \\
Stones \\
\end{tabular}} & \multirow{2}{*}{$\begin{array}{c}\text { Total } \\
\text { Carats } \\
(+0.85 \mathrm{~mm} \\
\end{array}$} \\
\hline & & $\begin{array}{l}+0.106 \\
-0.150 \\
\end{array}$ & $\begin{array}{r}+0.150 \\
-0.212 \\
\end{array}$ & $\begin{array}{l}+0.212 \\
-0.300 \\
\end{array}$ & $\begin{array}{l}+0.300 \\
-0.425 \\
\end{array}$ & $\begin{array}{r}+0.425 \\
-0.600 \\
\end{array}$ & \begin{tabular}{|l|}
+0.600 \\
-0.850 \\
\end{tabular} & $\begin{array}{r}+0.850 \\
-1.180 \\
\end{array}$ & \begin{tabular}{|r|}
+1.180 \\
-1.700 \\
\end{tabular} & \begin{tabular}{|l|}
+1.700 \\
-2.360 \\
\end{tabular} & \begin{tabular}{|l|}
+2.360 \\
-3.350 \\
\end{tabular} & $\begin{array}{l}+3.350 \\
-4.750 \\
\end{array}$ & $\begin{array}{l}+4.750 \\
-6.700 \\
\end{array}$ & & \\
\hline KDYKE & 0.2788 & 940 & 600 & 371 & 198 & 120 & 65 & 23 & 12 & 3 & 3 & - & - & 2,335 & 1.5916 \\
\hline KIMB1 & 3.2072 & 3,967 & 2,609 & 1,564 & 918 & 466 & 290 & 147 & 61 & 21 & 12 & 3 & - & 10,058 & 10.5379 \\
\hline KIMB2 & 955 & 703 & 480 & 296 & 174 & 87 & 61 & 18 & 9 & 5 & 2 & - & - & 1,835 & 1.6241 \\
\hline KIMB3 & 0.3961 & 753 & 495 & 302 & 174 & 85 & 57 & 35 & 21 & 2 & 1 & - & - & 1,925 & 1.4771 \\
\hline KIMB4 & 0.5208 & 367 & 250 & 134 & 101 & 49 & 30 & 11 & 8 & 5 & 3 & - & - & 958 & 1.4758 \\
\hline
\end{tabular}

Table 1. Diamond results by unit. A total of $2,090 \mathrm{~kg}$ of kimberlite was processed where only the +0.425 size fraction and above was recovered; these results are not included in this table. An additional minor kimberlite unit has been identified (KIMB5). At present, no material from this unit has been processed for diamond recovery. 


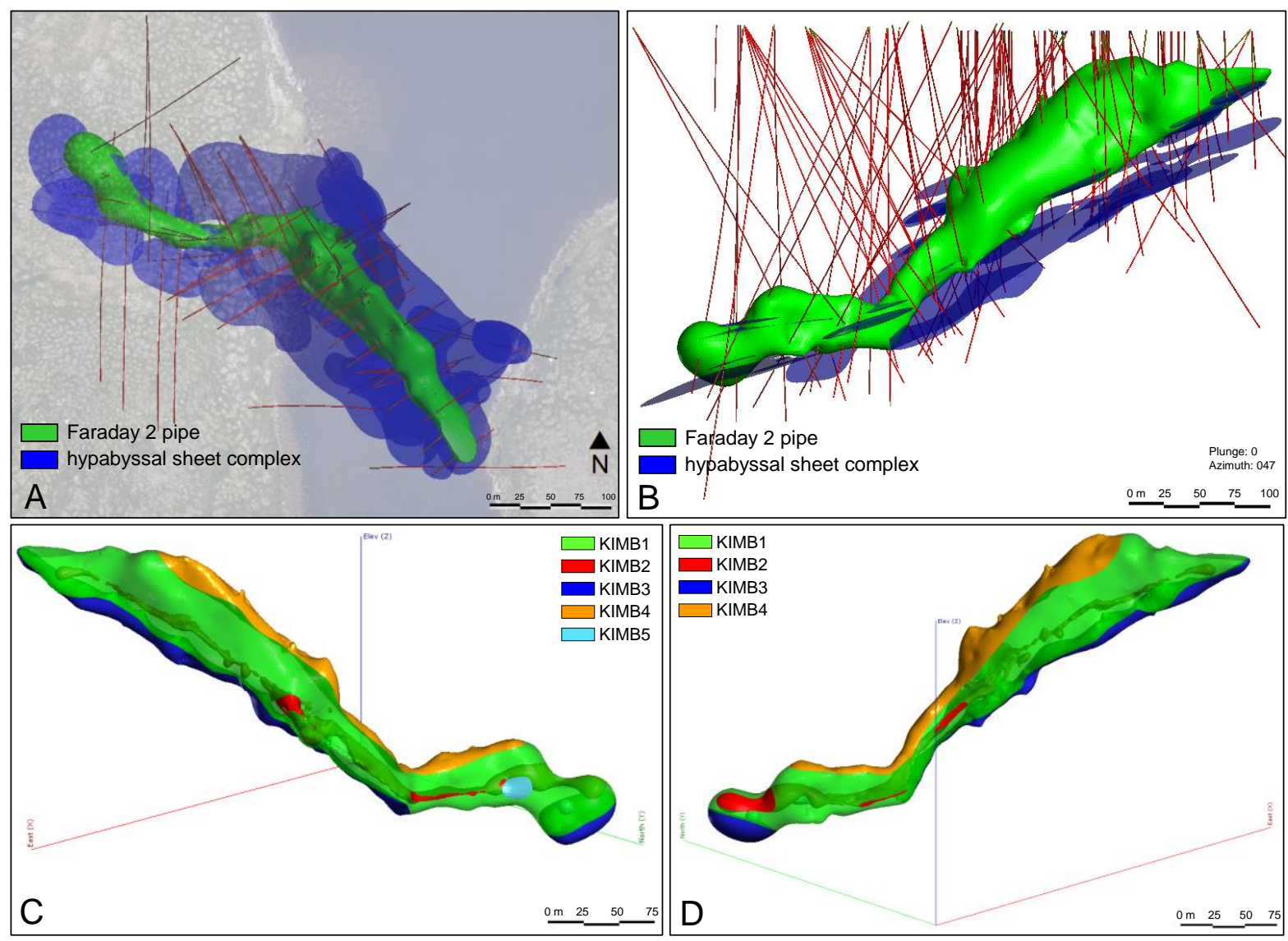

Figure 1. 3D model of the Faraday 2 kimberlite. (A) Plan view of the pipe with the surrounding hypabyssal kimberlite sheet complex and drill hole traces. (B) Oblique view of Faraday 2 looking northeast, with drill hole traces. (C) Internal geology of the pipe, looking southwest. KIMB1: volcaniclastic phlogopite kimberlite, KIMB2: coherent to transitional phlogopite kimberlite, KIMB3: coherent phlogopite kimberlite, KIMB4: volcaniclastic kimberlite with high country rock dilution and localized sorting, KIMB5: transitional phlogopite kimberlite (D) Internal geology of the pipe, looking northeast.
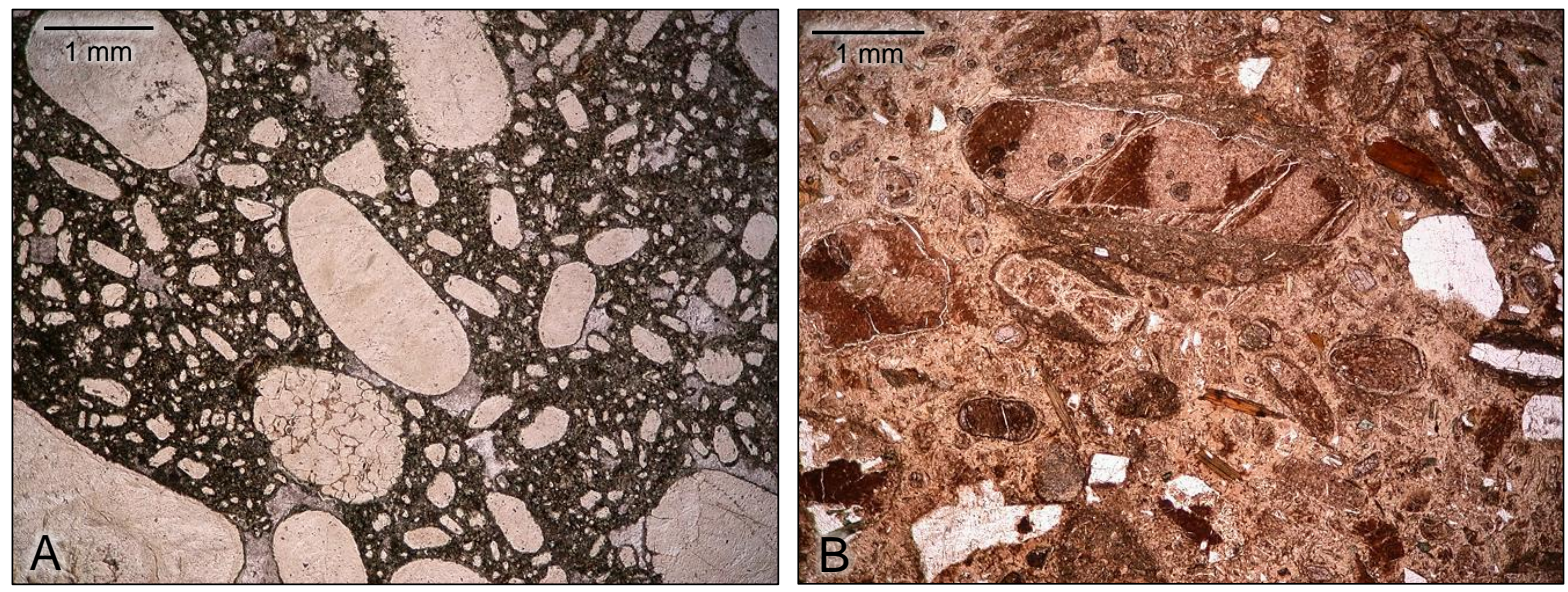

Figure 2. Photomicrographs of the two textural end-members at Faraday 2. (A) Coherent phlogopite kimberlite (KIMB3), olivine-rich with a continuous crystalline groundmass containing irregular segregations of carbonate. (B) Volcaniclastic phlogopite kimberlite (KIMB1) characterized by a loose-packed clast-supported texture with abundant thin-skinned pelletal-shaped magmaclasts and a microlitic serpentine matrix. Angular country rock xenoliths and xenocrysts are common. 


\section{Geology}

There are five distinct kimberlite units infilling the Faraday 2 pipe, which are differentiated by their textural characteristics, mineralogy, country rock dilution, interpreted emplacement relationships, and diamond grade. The units form layers with contacts that are sub-parallel to the upper and lower edges of the pipe (Figure 1). A marginal breccia (MB) of fractured and pulverized country rock with trace amounts of kimberlitic material occurs above the pipe. Hypabyssal kimberlite sheets (KDYKE) are associated with the pipe and dip towards the northwest.

The dominant pipe infill is volcaniclastic kimberlite (KIMB1 and KIMB4) with lesser amounts of coherent and transitional kimberlite (KIMB2, KIMB3 and KIMB5). KIMB1 comprises over 70\% of the pipe volume. It is a massive, olivine-rich phlogopite kimberlite characterized by thin-skinned pelletalshaped magmaclasts (formerly pelletal lapilli) and country rock xenoliths set within a matrix of serpentine and microlites. Well-formed acicular phlogopite phenocrysts are present in the melt selvedges of the magmaclasts. Country rock dilution of KIMB1 ranges between 30 and $40 \%$. Country rock xenoliths are predominantly locally-derived metasediment and amphibolite with rare granitoid and diabase. KIMB4 is a highly-diluted (>70\%) volcaniclastic phlogopite kimberlite that exhibits localized sorting. KIMB2 is a texturally variable phlogopite kimberlite with both volcaniclastic and coherent examples. It is characterized by olivine macrocrysts pseudomorphed by pale-coloured serpentine and serpentinized country rock shards set in a poorly-crystalline groundmass or serpentine matrix. KIMB3 is a massive, inequigranular, xenolith-poor, fine to coarse olivine-rich coherent phlogopite kimberlite. KIMB5 is a minor transitional kimberlite unit occuring in the deepest portion of the pipe. Mantlederived indicator minerals are rare in all units and primarily consist of peridotitic garnet.

\section{Conclusions}

The volcaniclastic kimberlite that is the main pipe infill at Faraday 2 (KIMB1) is further classified as a Kimberley-type pyroclastic kimberlite (KPK), formerly referred to as tuffisitic kimberlite breccia (TKB) (Smith et al., 2013). The second volcaniclastic kimberlite (KIMB4) has not been classfied as such due to the presence of sorting. KIMB4 was likely formed by gas-escape processes along the pipe margin.

The textures, mineralogy, and significantly diamondiferous nature of the kimberlite units at Faraday 2 are similar to the other bodies in the Kelvin-Faraday cluster and the Gahcho Kué kimberlite cluster (Hetman et al., 2004).

Faraday 2 is characterized by multiple kimberlite units representing multiple phases of kimberlite with separate emplacement events that have formed a non-typical inclined and irregular pipe. The subhorizontal, inclined orientation of the pipe, internal geology, and close relationship to kimberlite sheets within Faraday 2 are generally similar to the other kimberlites in the Kelvin-Faraday cluster. This inclined pipe orientation is atypical of previously-described KPK systems.

Faraday 2 is open at depth, and additonal drilling is required to determine the full extent of the kimberlite. In 2016 and 2017, a total of 284 tonnes of kimberlite was sampled by 11-inch RC drilling. The macrodiamond results from the 2017 program will be combined with previous data to support an inferred resource classification.

\section{References}

Hetman, C. M., Smith, B. S., Paul, J. L., \& Winter, F. (2004). Geology of the Gahcho Kue kimberlite pipes, NWT, Canada: root to diatreme magmatic transition zones. Lithos, 76(1), 51-74.

Smith, B. S., Nowicki, T. E., Russell, J. K., Webb, K. J., Mitchell, R. H., Hetman, C. M., and Robey, J. A. (2013). Kimberlite terminology and classification. In Proceedings of 10th International Kimberlite Conference (pp. 1-17). Springer India. 